\title{
A review of methods to measure tendon dimensions
}

\author{
Alex Hayes ${ }^{1,2^{*}}$, Katrina Easton ${ }^{6}$, Pavan Teja Devanaboyina ${ }^{3}$, Jian-Ping Wu ${ }^{4}$, Thomas Brett Kirk ${ }^{1,5}$ and David Lloyd ${ }^{3}$
}

\begin{abstract}
Tendons are soft tissues of the musculoskeletal system that are designed to facilitate joint movement. Tendons exhibit a wide range of mechanical properties matched to their functions and, as a result, have been of interest to researchers for many decades. Dimensions are an important aspect of tendon properties.

Change in the dimensions of tissues is often seen as a sign of injury and degeneration, as it may suggest inflammation or general disorder of the tissue. Dimensions are also important for determining the mechanical properties and behaviours of materials, particularly the stress, strain, and elastic modulus. This makes the dimensions significant in the context of a mechanical study of degenerated tendons. Additionally, tendon dimensions are useful in planning harvesting for tendon transfer and joint reconstruction purposes.

Historically, many methods have been used in an attempt to accurately measure the dimensions of soft tissue, since improper measurement can lead to large errors in the calculated properties. These methods can be categorised as destructive (by approximation), contact, and non-contact and can be considered in terms of in vivo and ex vivo.
\end{abstract}

Keywords: Tendon, Dimensions, Measurements, In vivo, Ex vivo

\section{Background \\ Tendons}

Tendons are a soft connective tissue designed to efficiently transfer loads generated by muscles to the skeletal system, facilitating joint movement $[1,2]$. These can be found as rounded cords, strap-like bands, or flattened ribbons, depending on their function. Tendons exhibit a complex hierarchical structure arranged longitudinally to resist the direction of most tension [3]. This hierarchy exhibits complex micromechanics that allow the muscletendon-bone construct to act efficiently. Tendons demonstrate viscoelastic behaviour [4-6]; that is, they exhibit time- and strain rate-dependent properties $[4,7,8]$.

Tendons primarily consist of water (65-70\% wet weight) and collagen type-I (70-80\% dry weight), with different types of collagen fibres, elastin, proteoglycans, and glycolipids making up the remainder [4, 9-13]. Collagen type-I represents approximately $95 \%$ of all collagen in

\footnotetext{
* Correspondence: alex.hayes@outlook.com.au

${ }^{1}$ Department of Mechanical Engineering, Curtin University of Technology,

Perth, Western Australia, Australia

${ }^{2}$ Medical Engineering and Physics, Royal Perth Hospital, Perth, Western

Australia, Australia

Full list of author information is available at the end of the article
}

the tendon, with the remaining $5 \%$ collagen type-III and type-V [14-17]. Collagen type-III is primarily found in aged and healing tendon, and normal tendon is mainly limited to the insertion sites of highly stressed tendons and in the endo- and epitenons [14, 16]. Glycosaminoglycans, glycoproteins, and proteoglycans make up the non-collagenous matrix components $[10,15,16,18]$. The non-collagenous matrix plays an important role within the tendon, including contributing to the mechanical properties [19], particularly the viscoelastic behaviour $[20,21]$. Tendons have a low cell density $(<5 \%)$ and this is thought to contribute to their limited healing capacity $[10,14]$.

Tendons exhibit properties such as stiffness, resilience, and strength, which allow for efficient transfer of forces from muscle to bone [22]. It has been observed that tendons exhibit a wide range of mechanical properties due to the breadth of functions performed [14, 23, 24]. As a result, tendon properties have been of interest to researchers for many decades [25-27]. Knowledge of the mechanical properties not only contributes to understanding of the tendon function but also provides inputs for computer simulations of the human body [28].

(c) The Author(s). 2019 Open Access This article is distributed under the terms of the Creative Commons Attribution 4.0 International License (http://creativecommons.org/licenses/by/4.0/), which permits unrestricted use, distribution, and 
The Achilles tendon is generally regarded as the strongest tendon in the human body [22, 29-31]. Forces of $1-4 \mathrm{kN}$ have regularly been measured during jumping and cycling, and peak forces of $9 \mathrm{kN}$, or 12.5 times body weight, have been measured during running at full speed $[15,16,18,30,32]$. The breaking stress of tendon is estimated to be $50-100 \mathrm{MPa}[14,26,32-36]$. Stresses in excess of $70 \mathrm{MPa}$ have been measured in vivo [32] and are regularly reported between 30 and $60 \mathrm{MPa}$ [8, 37-39]. Stress in the Achilles tendon in vivo has been estimated to be as high as $110 \mathrm{MPa}$ [40]. Hence, peak stress in vivo may in some cases exceed the measured ultimate tensile strength (UTS) of the tendon [18], illustrating the complexity of tendon mechanics in vivo.

\section{The problem}

Musculoskeletal conditions are common, with 30 million cases of injury reported annually worldwide [41]. Despite being the largest and strongest tendon in the body, the Achilles is reported to be involved in the most sports-related tendon injuries [31]. For example, injury is regularly seen in ageing athletes who participate in repetitive explosive activities [4, 42]. It has been reported that ruptured tendons show significant degeneration compared with normal controls [43, 44], suggesting disease may precede and possibly contribute to rupture. Degenerated tendons exhibit decreased mechanical properties, such as stiffness and UTS [45, 46], and are generally observed to be disordered with a larger cross-sectional area (CSA), a lower stiffness, and a lower elastic modulus [45, 47].

Disease of the tendon, known as tendinopathy, is characterised by pain and reduced mobility and functionality. The pathology is complex, including disordered healing causing fibre disruption and disorientation, generally with an absence of inflammatory cells. The aetiology and progression of the disease are not well known, leading experts to coin the term 'tendinopathy' to describe the clinical presentation of the condition [48, 49]. The prevalence of tendinopathy has been estimated at 11.83 per 1000 persons per year, with an incidence rate of 10.52 per 1000 persons per year [50]. Achilles tendinopathy has been reported to be as prevalent as 6-9\% of some populations [51], with $4 \%$ of sufferers going on to suffer rupture of the tendon [52].

Tendinopathy is traditionally considered an overuse injury caused by repetitive strain of the tendon $[4,15$, $18,53]$. While widely accepted, this view is unproven and has been challenged by several authors, including Arnoczky et al. [54] and Rees et al. [55]. Previous studies attempting to elucidate the aetiology of tendinitis found that repetitive loads caused microscopic failure of the collagen matrix, triggering an inflammatory response $[4,56]$. However, the lack of inflammatory markers in many cases means tendinitis can only be confirmed with histology, and thus, tendinopathy is the preferred term [55]. A recent hypothesis proposes that microdamage may lead to isolation of segments of the tendon which in turn leads to underuse [54].

The consequences of tendon injuries are pronounced, and the underlying causes and tissue responses must be better understood in order to develop improved treatment and prevention techniques. Due to a lack of evidence-based management, treatment has traditionally been conservative, with surgery considered the last resort due to the lack of evidence for its efficacy $[4,57]$. Conservative management techniques primarily aim to relieve the symptoms of tendinopathy [15]. Counterintuitively, many conservative treatment options now involve applying load to the tendon via eccentric exercise, but this remains controversial [18, 30, 55].

\section{Importance of measurements}

Changes in the dimensions of tissues are often seen as a sign of injury and degeneration, as an increased area may suggest swelling, inflammation, and general disorder of the tissue. This is true in tendinopathy, where affected tendons have exhibited larger CSA compared to controls [47]. CSA is also an important measurement for determining the mechanical properties and behaviours of materials, particularly the stress, strength, and elastic modulus of the material. This makes CSA a significant measurement in the context of a mechanical study of degenerated tendons. Large errors in stress calculations can occur due to inaccurate measurement of an object's CSA [58].

One assumption commonly made when assessing the mechanical properties of tendon is that the CSA remains constant and is uniform along the length of the specimen. Thus, CSAs are measured at a single location or averaged over several measurements, thereby allowing for loads to be converted to engineering stresses posttesting $\left(\sigma_{\mathrm{E}}=F / A_{0}\right.$, where $\sigma_{\mathrm{E}}$ represents the engineering stress, $F$ is the force, and $A_{0}$ is the original area). According to Poisson's effect, the transverse strain changes with axial strain, resulting in changes to CSA. In many situations, the engineering stress gives a reasonable approximation; however, even at low loads, a difference can be detected [59]. It is therefore desirable to measure the true stress, the force divided by the actual area $\left(\sigma_{\mathrm{T}}=\right.$ $\left.F / A_{\mathrm{i}}\right)$, to better estimate the stress experienced by soft tissue. This requires measurement of both instantaneous and local CSA along a sample, which can be used to better define the relationship between stress and strain [59], as well as to develop more accurate geometric models for finite element analysis (FEA) [60]. The limitation is due, in part, to the lack of simple three-dimensional (3D) measurement techniques capable of measuring CSA along the length of the specimen. 
Soft biological tissue samples have irregular shapes and are load-, rate-, and time-sensitive. Therefore, the measurement technique must be considered in order to achieve an accurate result. Additionally, tendon dimensions are useful in planning harvesting for tendon transfer and joint reconstruction purposes [61-63].

Over the years, many methods have been employed in an attempt to accurately measure CSA of soft tissue, since inaccuracies can result in large errors when calculating the stress [58]. These methods can be categorised as destructive (by approximation), contact, and non-contact [64]. Furthermore, these methods can be considered in terms of in vivo and ex vivo techniques.

\section{In vivo measurement techniques}

Tendon dimensions are often used as an indication of injury and degeneration [47], as well as in the planning of tendon harvesting [61-63]. Therefore, clinically available in vivo measurement techniques are important. Modalities such as ultrasonography (US), computed tomography $(\mathrm{CT})$, and magnetic resonance imaging (MRI) are prevalent in the clinical environment (Table 1). In particular, MRI and US are useful imaging modalities for visualising tendon morphology $[65,66]$.

\section{Computed tomography}

$\mathrm{CT}$ is a common imaging technique for diagnostic and preoperative planning, making it an attractive option for observing tendon dimensions. However, the low $\mathrm{x}$-ray attenuation of soft tissues can make them difficult to distinguish. Yasumoto et al. [63] demonstrated that CT can be an effective tool for measuring the length, but not the area, of the semitendinosus for anterior cruciate ligament (ACL) graft planning, while Schepull et al. [67] utilised CT to measure the area of the Achilles tendon. This is likely due to the difference in volume of soft tissue surrounding each tendon, resulting in easier differentiation of the Achilles tendon compared to the semitendinosus. One method of improving the contrast of the tissues is to utilise a staining agent $[68,69]$. While improving the quality and information available in the acquired images, this technique is limited to ex vivo evaluations and prolonged staining of the tissue has been associated with shrinkage and deformation of the tissue [68]. Due to the diffusion times required for the agents, it is unlikely that this technique would be transferable to a clinical setting.

\section{Magnetic resonance imaging}

MRI has been used to measure Achilles tendon [70-72] and patellar tendons [73-76]. Despite MRI being a common technique, few studies have reported robust methodologies for measuring tendon dimensions. Many reported techniques have focused on finding a correlation between anthropomorphic measurements, particularly height, and the dimensions of graft tendons for preoperative planning $[62,74,75]$. Similarly, CSA measurements of tendon graft using MRI have been shown to correlate with final graft CSA in ACL reconstruction [61, 62, 77-81]. Tendon-only length was also shown to correlate with the intraoperative tendon-only length of gracilis and semitendinosus tendons [82], while no correlation has been reported between preoperative diameter measurements and the final diameter [80]. The majority of studies calculated the CSA using a graft sizing block and 'by estimation' approach, thereby limiting the accuracy of the intraoperative tendon measurements.

Chang et al. [76] performed intraoperative patellar tendon measurements using a ruler, showing high accuracy and reliability of the measurements. Hamada et al. [83] reported a close positive correlation between preoperative MRI and intraoperative CSA measurements using an area micrometre. However, the MRI measurements were shown to underestimate the intraoperative measurements by almost $10 \%$. This was also seen by Couppe et al. [84], in a horse cadaver model, when comparing measurements on greyscale MRI to ex vivo casting measurements. An improvement in accuracy was demonstrated by adjusting the colour scale of the MRI images to better delineate the tendon from the surrounding tissues [84]. In defining the tendon boundary, consideration must be given to the thickness of the paratenon [72], the boundary of which may not be clear on greyscale imaging.

\section{Ultrasonography}

US is an inexpensive, safe, fast, and reliable non-invasive technique for imaging tendon, including pathology and geometry [39, 45, 85-89]. US has been shown to be a suitable alternative to MRI for tendon measurements [79] and is a less expensive technique [90]. US has been used to measure tendon dimensions, including thickness, length, and area, and is particularly suited to large superficial tendons such as the Achilles [91-104] and patellar tendons $[39,45,89,105,106]$.

Similar to MRI, US has been used to look at correlations in tendon size with anthropomorphic measurements. Patel and Labib [85] investigated various Achilles tendon parameters (length, width, thickness, and CSA) and found they correlated positively with subject height, weight, tibia length, and foot size. The Achilles tendon CSA correlated significantly with the activity level.

The results of the accuracy and reliability of US in literature has been conflicted. Some reports have described US as unreliable as a technique for measuring tendon in vivo, while others describe it as reliable and accurate [85, 107, 108]. For example, US measurements of the gracilis and semitendinosus have been shown to be both 
Table 1 Summary of techniques to measure the dimensions and geometries of soft tissues and their clinical value

\begin{tabular}{|c|c|c|c|c|}
\hline Technique & Papers & Advantages & Disadvantages & Clinical value \\
\hline $\begin{array}{l}\text { Anthropomorphic } \\
\text { correlations }\end{array}$ & {$[62,74,75,85]$} & $\begin{array}{l}\text { - Simple } \\
\text { - Fast }\end{array}$ & $\begin{array}{l}\text { - Limited reliability } \\
\text { - Inherent errors due to assumptions } \\
\text { - Not truly patient-specific } \\
\text { - Lack of quality physical measurements } \\
\text { for comparison }\end{array}$ & $\begin{array}{l}\text { Limited clinical usefulness } \\
\text { due to assumptions and low } \\
\text { reliability }\end{array}$ \\
\hline Ruler & [76] & $\begin{array}{l}\text { - Simple } \\
\text { - Fast }\end{array}$ & $\begin{array}{l}\text { - Unable to measure two- or three- } \\
\text { dimensional geometry }\end{array}$ & $\begin{array}{l}\text { Clinically useful due to } \\
\text { simplicity }\end{array}$ \\
\hline $\begin{array}{l}\text { Computed } \\
\text { tomography }(\mathrm{CT})\end{array}$ & {$[63,67,135,136]$} & $\begin{array}{l}\text { - Readily available diagnostic } \\
\text { imaging technique } \\
\text { - Non-contact } \\
\text { - Non-invasive } \\
\text { - Three-dimensional }\end{array}$ & $\begin{array}{l}\text { - Poor discrimination of soft tissues } \\
\text { - Radiation dose } \\
\text { - Lack of quality physical measurements } \\
\text { for comparison }\end{array}$ & $\begin{array}{l}\text { Limited clinical usefulness } \\
\text { due to poor discrimination } \\
\text { of soft tissues }\end{array}$ \\
\hline $\begin{array}{l}\text { Computed } \\
\text { tomography } \\
\text { with contrast }\end{array}$ & {$[68,69]$} & $\begin{array}{l}\text { - Improved differentiation of } \\
\text { soft tissues } \\
\text { - Non-contact } \\
\text { - Non-invasive } \\
\text { - Three-dimensional }\end{array}$ & $\begin{array}{l}\text { - Limited to ex vivo evaluations } \\
\text { - Potential deformation of tissue } \\
\text { - Poor discrimination of soft tissues } \\
\text { - Radiation dose }\end{array}$ & $\begin{array}{l}\text { Limited clinical usefulness } \\
\text { due to difficulty applying } \\
\text { contrast agents }\end{array}$ \\
\hline $\begin{array}{l}\text { Magnetic } \\
\text { resonance } \\
\text { imaging (MRI) }\end{array}$ & $\begin{array}{l}{[61,62,70-84,} \\
137,138]\end{array}$ & $\begin{array}{l}\text { - Readily available diagnostic } \\
\text { imaging technique } \\
\text { - Able to differentiate soft tissues } \\
\text { - Image quality can be improved } \\
\text { with digital post-processing } \\
\text { - Safe } \\
\text { - Non-contact } \\
\text { - Non-invasive } \\
\text { - Three-dimensional }\end{array}$ & $\begin{array}{l}\text { - Expensive } \\
\text { - Slow } \\
\text { - Lack of robust methodologies } \\
\text { - Conflicted reports of accuracy } \\
\text { and reliability } \\
\text { - May not adequately resolve paratenon } \\
\text { - Lack of quality physical measurements } \\
\text { for comparison }\end{array}$ & $\begin{array}{l}\text { Clinically useful due to clear } \\
\text { differentiation of soft tissues }\end{array}$ \\
\hline $\begin{array}{l}\text { Ultrasound, } \\
\text { 2D (2DUS) }\end{array}$ & $\begin{array}{l}{[39,45,66,73,78} \\
79,85-115]\end{array}$ & $\begin{array}{l}\text { - Readily available for diagnostic } \\
\text { imaging technique } \\
\text { - Safe } \\
\text { - Fast } \\
\text { - Non-invasive } \\
\text { - Inexpensive } \\
\text { - Able to differentiate soft tissues }\end{array}$ & $\begin{array}{l}\text { - Two-dimensional } \\
\text { - Conflicted reports of accuracy and } \\
\text { reliability for deep tendons } \\
\text { - Results dependent on operator, } \\
\text { pressure, position, and orientation } \\
\text { - Lack of quality physical measurements } \\
\text { for comparison } \\
\text { - Unable to detect paratenon } \\
\text { - Requires contact }\end{array}$ & $\begin{array}{l}\text { Clinically useful for superficial } \\
\text { tendons }\end{array}$ \\
\hline $\begin{array}{l}\text { Ultrasound, } \\
\text { 3D (3DUS) }\end{array}$ & [117-121] & $\begin{array}{l}\text { - Accurate } \\
\text { - Reliable } \\
\text { - Repeatable } \\
\text { - Reduced operator-, position-, } \\
\text { and orientation-dependency } \\
\text { - Safe } \\
\text { - Fast } \\
\text { - Non-invasive } \\
\text { - Three-dimensional } \\
\text { - Able to differentiate soft tissues }\end{array}$ & $\begin{array}{l}\text { - Unable to detect paratenon } \\
\text { - Requires contact } \\
\text { - Pressure dependency }\end{array}$ & $\begin{array}{l}\text { High clinical usefulness for } \\
\text { superficial tendons }\end{array}$ \\
\hline Sectioning & {$[27,124,125]$} & $\begin{array}{l}\text { - Accurate } \\
\text { - Repeatable } \\
\text { - Can be reconstructed to three- } \\
\text { dimensional }\end{array}$ & - Destructive & $\begin{array}{l}\text { Low clinical usefulness due } \\
\text { to destructive nature }\end{array}$ \\
\hline By estimation & {$[126]$} & $\begin{array}{l}\text { - Simple } \\
\text { - Fast }\end{array}$ & $\begin{array}{l}\text { - Inherent errors due to shape } \\
\text { assumptions } \\
\text { - Does not capture geometry } \\
\text { - Affected by measurement } \\
\text { technique (e.g. ruler) }\end{array}$ & $\begin{array}{l}\text { Clinically useful for } \\
\text { comparative measurements }\end{array}$ \\
\hline Area micrometry & [126-128] & $\begin{array}{l}\text { - Simple } \\
\text { - Fast } \\
\text { - Repeatable }\end{array}$ & $\begin{array}{l}\text { - Underestimates area } \\
\text { - Contact } \\
\text { - Does not capture geometry }\end{array}$ & $\begin{array}{l}\text { Clinically useful for } \\
\text { comparative measurements }\end{array}$ \\
\hline Casting & [129-131] & $\begin{array}{l}\text { - Accurate } \\
\text { - Reliable } \\
\text { - Repeatable } \\
\text { - Three-dimensional } \\
\text { - Ability to revisit measurements }\end{array}$ & $\begin{array}{l}\text { - Slow } \\
\text { - Contact } \\
\text { - Requires tissue to be isolated } \\
\text { - Unable to visualise internal structures }\end{array}$ & $\begin{array}{l}\text { Clinically useful for some } \\
\text { tissues, particularly resected } \\
\text { tissues }\end{array}$ \\
\hline
\end{tabular}


Table 1 Summary of techniques to measure the dimensions and geometries of soft tissues and their clinical value (Continued)

\begin{tabular}{|c|c|c|c|c|}
\hline Technique & Papers & Advantages & Disadvantages & Clinical value \\
\hline $\begin{array}{l}\text { Shadow } \\
\text { amplitude }\end{array}$ & [126] & $\begin{array}{l}\text { - Accurate } \\
\text { - Non-contact }\end{array}$ & $\begin{array}{l}\text { - Poor repeatability } \\
\text { - Unable to visualise internal structures }\end{array}$ & Limited clinical usefulness \\
\hline $\begin{array}{l}\text { Laser } \\
\text { micrometry }\end{array}$ & $\begin{array}{l}{[4,59,60,64,132} \\
134,139,140]\end{array}$ & $\begin{array}{l}\text { - Fast } \\
\text { - High accuracy } \\
\text { - Repeatable } \\
\text { - Reliable } \\
\text { - Non-contact } \\
\text { - Two-dimensional }\end{array}$ & $\begin{array}{l}\text { - Affected by specimen geometry, } \\
\text { concavities, opacity, reflectivity, } \\
\text { and orientation } \\
\text { - Unable to visualise internal structures }\end{array}$ & $\begin{array}{l}\text { Limited to external and } \\
\text { ex vivo measurements }\end{array}$ \\
\hline Laser scanning & [142] & $\begin{array}{l}\text { - Fast } \\
\text { - High accuracy } \\
\text { - Repeatable } \\
\text { - Reliable } \\
\text { - Non-contact } \\
\text { - Three-dimensional }\end{array}$ & $\begin{array}{l}\text { - Affected by specimen geometry, } \\
\text { concavities, surface refraction, } \\
\text { alignment of sample, opacity, } \\
\text { reflectivity, and orientation } \\
\text { - Limited viewing window for } \\
\text { three-dimensional reconstruction } \\
\text { - Unable to visualise internal structures }\end{array}$ & $\begin{array}{l}\text { Clinically useful for 3D } \\
\text { surface measurements. } \\
\text { Limited to external and } \\
\text { ex vivo tissues }\end{array}$ \\
\hline Photogrammetry & [143] & $\begin{array}{l}\text { - High accuracy } \\
\text { - Repeatable } \\
\text { - Reliable } \\
\text { - Non-contact } \\
\text { - Three-dimensional } \\
\text { - Photorealistic reconstruction }\end{array}$ & $\begin{array}{l}\text { - Affected by concavities } \\
\text { - Unable to visualise internal structures }\end{array}$ & $\begin{array}{l}\text { Clinically useful for 3D } \\
\text { surface measurements. } \\
\text { Limited to external and } \\
\text { ex vivo tissues }\end{array}$ \\
\hline $\begin{array}{l}\text { Structured white } \\
\text { light }(S W L)\end{array}$ & [144-146] & $\begin{array}{l}\text { - Fast } \\
\text { - High accuracy } \\
\text { - Repeatable } \\
\text { - Reliable } \\
\text { - Non-contact } \\
\text { - Three-dimensional } \\
\text { - Photorealistic reconstruction }\end{array}$ & $\begin{array}{l}\text { - Affected by small concavities } \\
\text { - Unable to visualise internal structures }\end{array}$ & $\begin{array}{l}\text { Clinically useful for 3D } \\
\text { surface measurements. } \\
\text { Limited to external and } \\
\text { ex vivo tissues }\end{array}$ \\
\hline $\begin{array}{l}\text { Digital image } \\
\text { correlation (DIC) }\end{array}$ & [147-155] & $\begin{array}{l}\text { - Fast } \\
\text { - High accuracy } \\
\text { - Repeatable } \\
\text { - Reliable } \\
\text { - Non-contact } \\
\text { - Three-dimensional }\end{array}$ & $\begin{array}{l}\text { - Requires sample preparation } \\
\text { - Affected by small concavities } \\
\text { - Unable to visualise internal structures }\end{array}$ & $\begin{array}{l}\text { Clinically useful for 3D } \\
\text { surface and strain } \\
\text { measurements. Limited } \\
\text { to external and ex vivo } \\
\text { tissues }\end{array}$ \\
\hline
\end{tabular}

correlated [78, 79] and not correlated [109] with preoperative calculations for hamstring graft in anterior cruciate repairs. Operator dependence is a known factor in US $[66,90]$ and is a known limitation in the accuracy and reliability of the technique [86], while position and measurement location are highly important for reliability [110].

Authors such as Ying et al. [96] and Barfod et al. [111] have proposed clinically applicable, standardised methods for measuring tendon geometry in an attempt to improve the reliability and accuracy of US measurements independent of the operator. A work by Skou and Aalkjaer [86] found that changes in a patellar tendon larger than $0.7 \mathrm{~mm}$ could be detected by the same operator, while changes of $1 \mathrm{~mm}$ could be detected by different operators. They highlighted the importance of standardised methods in improving US measurements. A recent review of papers analysing diagnostic measures of tendon size reported that the measurement error associated with reliability is less than the difference in the size of symptomatic and asymptomatic tendons [108]. Recent studies, using MRI for baseline measurements, demonstrated the accuracy and reliability of US for measuring tendon length in the
Achilles tendon. Reeves et al. [88] measured CSA of the patellar tendon using US, finding strong agreement in measurements taken by the same operator on separate days. A follow-up study by Reeves et al. [87] showed a close inter-method agreement with MRI and included a morphometric analysis of a phantom using MRI to determine accuracy.

In contrast, Ekizos et al. [73] and Bohm et al. [112] found US unsuitable for accurate measurement in vivo. Bohm et al. [112] and Kruse et al. [110] reported that US underestimated the CSA of the Achilles tendon, while Ekizos et al. [73] found US had a low reliability, including time, position, and observer differences. Some of the limitations included low visibility and blurry boundaries in the US images. Transducer pressure has also been shown to affect tendon measurement $[91,95,110,113]$.

A significant shortcoming of many studies is the lack of high-quality physical measurements of the tendons. Kruse et al. [110] noted that, without physical measurements, it is possible that MRI overestimates the measurement, rather than the reported conclusion that US underestimates tendon CSA. 
The accuracy of US has been demonstrated in ex vivo testing. Noguchi et al. [114] demonstrated US measurements to be as effective in measuring tendon and ligament specimens as 'by estimation' methods, using digital callipers, while preserving the morphology of the tissue. A significant limitation of the study was the assumption of a rectangular tendon for the purposes of estimating the CSA. A second limitation is the risk of overestimating the CSA due to fluid absorption, as the tissue must be imaged in a bath of saline which may affect the physiological hydration of the tissue. Du et al. [115] used US and laser micrometry in a customised rig to measure tendon dimensions during mechanical loading. US measurements of thickness were found to correlate highly with the laser measurements with increasing load. No measurement of CSA using US was reported for comparison.

Three-dimensional freehand ultrasound (3DUS) uses a combination of two-dimensional US (2DUS) and 3D motion capture to generate a $3 \mathrm{D}$ reconstruction of tissues. This technique has been shown to be accurate and reliable against MRI and phantoms [116, 117], and may overcome several limitations of 2DUS, including probe position and orientation. 3DUS has been used primarily on the Achilles tendon [116-122], with high reliability $[118,121]$ and repeatability [116].

Fan [122] demonstrated freehand technique, using a motion sensor, to create a $3 \mathrm{D}$ reconstruction of the Achilles tendon. This technique utilised only one subject, with no assessment of reliability or accuracy. Obst et al. [117] demonstrated the accuracy of the technique using phantoms as well as the reliability of in vivo measures of the Achilles tendon volume, length, and average CSA. A limitation of this technique is the inability to detect the thickness of the tendon paratenon, epitenon, and peritendinous space [118], which has previously been identified as a source of measurement error [72].

\section{Limitations}

While there are various ways to measure tendon in vivo, the choice of measurement technique must be evaluated for its suitability to the experiment. The importance of accurate measurement has been well described [58]. In addition to improved calculation of tendon stresses and strains, knowledge of tendon dimensions has been shown to aid in planning involving tendon grafting [61, 62, 7683 ] and in the identification of tendon disorders [47].

The lack of consensus in the literature is a confounding factor in deciding which technique to use. For example, it has been reported that tendon dimensions differ between US and MRI $[110,113]$ and are, therefore, not interchangeable [110] except under certain conditions [123]. It has also been reported that both techniques are independently reliable [110] and, conversely, that the reproducibility of MRI and US is a limitation [113]. These conflicting findings can make it difficult to determine which technique is most suitable for a particular study. A limitation of many of these studies is the lack of physical measurements for comparison [123].

This limitation is a recurring theme in the literature. The lack of high-quality control measurements when assessing the accuracy of in vivo measurement techniques makes it difficult to adequately compare between studies and between methods. This limitation is in part due to the inherent difficulty in acquiring physical measurements in vivo. A significant opportunity to acquire these physical measurements is in the form of intraoperative measurements. However, these measurements tend to be performed using graft sizing blocks and rulers, which do not provide sufficient accuracy to determine the 'true' dimensions of the tendon. Studies by Hamada et al. [83] and Couppe et al. [84] demonstrated the importance of these 'true' measurements in determining the accuracy of in vivo measurement techniques.

Many advanced measurement techniques are incompatible with the in vivo environment. However, these may be useful in providing control measurements of phantom or intraoperative measurements.

\section{Ex vivo measurement techniques Contact methods}

Historically, specimens were sectioned and traced, and the areas are measured using a planimeter [27]. This method is inherently destructive and prevents further testing of the sample. Chatzistergos et al. [124] measured tendon CSA by taking sections of the tissue post-rupture. This assumes no plastic deformation has occurred during testing, as this may influence the final shape of the tissue. More recently, Iriuchishima et al. [125] evaluated CSA of ACL versus the grafts used to replace them. The authors revisited Cronkite's technique and sectioned ACL at the bone attachments and through the midsection. With the use of digital photography and image processing they were able to measure CSA with a higher degree of accuracy and reproducibility. The authors did not discuss a method for measuring CSA of the grafts in a non-destructive fashion, limiting the clinical value of the study. It was, however, noted that a 3D measurement system would provide a higher degree of anatomical accuracy due to the natural path of the ligament.

'By estimation' techniques have ranged from estimating the shape of the specimens and measuring the height and width of the sample to 'fit' the shape, to the gravimetric method of calculating the area based on the length and volume and even ocular micrometry [126]. These techniques often assume uniformity within the tissue and, while simple, can introduce errors such as those discussed by Seitz et al. [58]. 
Area micrometry allows for irregularity in the shape of soft tissue by using adjustable blocks to compress the tissue into a channel with known size, from which the volume can be calculated [126-128]; however, these measurements generally underestimate CSA [59].

Race and Amis [129] approached the measurement of CSA differently, taking a silicone rubber cast and creating poly-methyl methacrylate replicas of the tissue for analysis. This technique was developed further by Goodship and Birch [130] and Schmidt and Ledoux [131] using new materials and improved techniques. Images were taken of the replicas and then analysed in silico to measure the area. These newer techniques were shown to improve measurement accuracy compared to existing methods. The casting method offers the advantage of being able to revisit measurements as the cast can be preserved even after destructive testing of the tendon.

\section{Non-contact methods}

Non-contact methods of measuring tendon dimensions offer significant advantages in terms of speed and usability. Shadow amplitude was developed in the 1960s to measure whole tissues. Of the aforementioned techniques, it was identified as the only non-destructive method able to be adapted to measure local CSAs [126]. It was also noted that there was an inherent need for refinement in the measuring of CSAs, due to the poor repeatability of the technique and inability to identify concavities.

Technological changes have led to improved non-contact devices, such as laser micrometres developed by Lee and Woo [4, 132], video dimension analysers [133], and charge-coupled device (CCD) laser sensors [134], as well as advances in medical imaging, including CT [69, 135, 136], MRI [137, 138], and US [114]. When evaluating their new technique, Race and Amis [129] pointed out that laser micrometry is potentially the most precise method of measuring the tendon; however, it is affected by specimen geometry and concavities, which also make it potentially the least accurate when dealing with complex shapes, leading researchers to develop new ways to measure CSA as technology improved.

Langelier et al. [60] developed a new computer-controlled laser micrometre based on the work of Lee and Woo [132]. The system utilised a $10-\mu \mathrm{m}$ laser and was found to be accurate and highly repeatable, but unable to identify concavities in the tissue. Liu et al. [139] proposed the use of a coordinate measurement machine, utilising laser micrometry of $1 \mu \mathrm{m}$ to scan the tendon. This method was shown to be more accurate than that developed by Langelier et al. [60] when scanning a standard block ( $0.4 \%$, with $1.6 \%$ repeatability); however, the tendon measurements were only compared to the less accurate shape-fitting technique.
Translucency of tendon is a known issue in microscopic investigation of tissue and may inhibit laser-based measurement due to refraction of light at the surface. Langelier et al. [60] discussed this issue and attributed it to the density of the sample being insufficient to interrupt the laser beam; however, this does not exclude the issue of refraction playing a part. Neither Langelier et al. [60] nor Liu et al. [139] evaluated their techniques against reliable existing methods; thus, the accuracy and repeatability of their experiments may be lower than reported when applied to hydrated soft tissue.

Moon et al. [134] trialled CCD laser sensors to address some of these issues, finding that the new system was able to measure concavities in an accurate and repeatable fashion. It was, however, susceptible to underestimation of CSA due to laser penetration of the semitransparent surface of the tissue. Therefore, the tendon was stained with Indian ink to provide a reflective coating. The system was also limited to objects with CSA larger than $20 \mathrm{~mm}^{2}$. It was noted that the improvements over other measurement techniques were negligible for rabbit ligaments and tendon [134].

Salisbury et al. [140] sought to develop a new method for characterising CSA, using a laser-slice method. The technique was effective at measuring the concavities in CSA profile and did not require any surface modification. The tendon was required to be rotated almost perfectly vertical in order to accurately measure CSA, which limited the potential use on tissues which have a 3D anatomical path. The accuracy was comparable to other methods but was deemed cheaper and more reliable when dealing with cavities than other methods.

The importance of understanding the local variations in shape and area in soft tissues has previously been identified in relation to the development of CSA measurement systems $[60,141]$. These papers discussed calculating local stresses and strains based on the local shape data. This information improves understanding of how the tissue changes with load and may be used to create more accurate FEA models. To date, almost all methods have required researchers to measure CSA outside of a materials testing system (MTS). This can often mean the condition of the sample can change between the measurement of CSA and the final testing procedure [59]. It is not necessarily practical to measure the tendon immediately prior to testing, such as when using cryogrips [59]. Therefore, in an ex vivo setting, a measurement system capable of integration with an MTS is desirable. The importance of measuring the instantaneous CSA so that true stress can be calculated has previously been discussed [59].

Pokhai et al. [59] developed a laser reflectance system for an MTS; however, it is sensitive to opacity, reflectivity, and orientation, as well as small specimen size and 
small concavities. Vergari et al. [64] developed a linear scanner to measure CSA of the tendon. While this method is much faster (under $2 \mathrm{~s}$ per measurement) than existing techniques, and also highly accurate (less than $2 \%$ error), it is limited in the shapes that are measurable, due to the linearity of the measurements. As with previous techniques, it is only able to measure one region at a time, meaning that whole tendon shape data are not available during mechanical testing. Heuer et al. [142] developed a 2D laser scanner to measure the deformation of an intervertebral disc in three dimensions. This scanner cannot distinguish tissue morphological complexities such as concavities and has a relatively limited viewing window.

Recent developments in 3D laser and structured light scanning (SLS), as well as advanced digital image correlation (DIC), have made these techniques affordable and suitable options for research.

Hashemi et al. [143] utilised a commercially available 3D photographic scanner to scan the ACL. The scanning process was approximately $30 \mathrm{~min}$, from which a $3 \mathrm{D}$ model was generated. The accuracy was similar to that seen with early laser micrometres; however, it also lacked the ability to detect concavities. The advantage of this technique over the laser-based systems is that CSA can be calculated at any point along the length of the tissue.

Three-dimensional structured white light (SWL) scanners have been used by Nebel [144] to create photorealistic 3D models of human bodies with an accuracy of $1 \mathrm{~mm}$. These models were then converted to FEA-compatible models. More recently, Ahn et al. [145] used a 3D SWL scanner to evaluate the changes in the dentoalveolar protrusion in patients before and after orthodontic work. This involved scanning the face from three angles simultaneously and reconstructing the model to ensure that any change between angles was not a product of patient movement or positioning.

Hayes et al. [146] reported a technique, using SLS, to measure CSA of biological tissue. The technique was shown to be fast, simple, and accurate, with minimal sample preparation. The technique demonstrated a high degree of repeatability and was able to capture the entire geometry, thereby enabling true stresses to be calculated along the sample.

DIC has been used to investigate the deformation of biological materials under load [147-153]. The principle of DIC is to detect gradient differences in a greyscale image to find patterns which can subsequently be tracked between images. This often requires application of an irregular pattern of similar-sized dots to the material. This has led to DIC sometimes being referred to as 'speckle imaging'. There are currently methods of calculation able to determine sub-pixel resolution of the strain fields [154].
Commercial packages are available that utilise stereophotogrammetry to map the strain field in 3D. The limitation of this system is usually in applying the speckle pattern, which must be fine and irregular, but with good contrast to enable visualisation of the gradient. The technique allows for the use of high resolution or high-speed cameras to maximise the quality of data captured. However, a big advantage of DIC over other modalities is the ability to record local strain in addition to calculating the shape data. Evans et al. [155] have previously discussed the advantages of using DIC in mechanical testing, as it provides more information, such as differences between regions of the test sample, which would otherwise be unmeasurable.

\section{Conclusion}

Knowledge of tendon dimensions has been shown to aid in the identification of tendon disorders and in planning for tendon grafting. Accurate measurement of tendon dimensions is important for calculating tendon stress and strain, as well as determining the difference between normal and degenerated tendon. Additionally, reliability, repeatability, and reproducibility are important considerations in the selection of measurement techniques, as they affect the ability to compare results within and between studies. Understanding these factors, as well as the environment of operation, is a key to determining the suitability of a measurement technique.

A recurring theme in the study of in vivo tendon measurements is the lack of control measurements to confirm the accuracy of the described techniques, thereby limiting the ability to compare between techniques and studies. Consensus on the results of in vivo techniques in the literature is limited and is affected by the lack of control measurements to determine the accuracy of these techniques. This severely limits the ability to compare between techniques and studies. Therefore, the use of control measurements is recommended to improve the reporting of tendon dimensions in literature.

\section{Abbreviations \\ 2D: Two-dimensional; 2DUS: Two-dimensional ultrasonography; 3D: Three- dimensional; 3DUS: Three-dimensional ultrasonography; ACL: Anterior cruciate ligament; CCD: Charge-coupled device; CSA: Cross-sectional area; CT: Computed tomography; DIC: Digital image correlation; FEA: Finite element analysis; MRI: Magnetic resonance imaging; MTS: Materials testing system; SLS: Structured light scanning; SWL: Structured white light; US: Ultrasonography; UTS: Ultimate tensile strength}

\section{Acknowledgements}

The authors would like to acknowledge the other members of the ARC Linkage project, LP110100581, for their contributions.

\section{Funding}

AJH received financial support from the Australian Government Research Training Program Scholarship. This research was funded by the Australian Research Council (LP110100581).

Availability of data and materials Not applicable. 


\section{Authors' contributions}

AJH, PTD, and KLE planned and wrote the manuscript. JPW, TBK, and DGL contributed to the planning and reviewing of the manuscript. All authors read and approved the final manuscript.

\section{Authors' information}

Not applicable.

\section{Ethics approval and consent to participate}

Not applicable.

\section{Consent for publication}

Not applicable.

\section{Competing interests}

The authors declare that they have no competing interests.

\section{Publisher's Note}

Springer Nature remains neutral with regard to jurisdictional claims in published maps and institutional affiliations.

\section{Author details}

'Department of Mechanical Engineering, Curtin University of Technology, Perth, Western Australia, Australia. ${ }^{2}$ Medical Engineering and Physics, Royal Perth Hospital, Perth, Western Australia, Australia. ${ }^{3}$ Centre for Musculoskeletal Research, Menzies Health Institute Queensland, Griffith University, Gold Coast, Queensland, Australia. ${ }^{4}$ Academy of Advanced Interdisciplinary Studies and the Department of Biomedical Engineering of Southern University of Science and Technology, No 1088, Xueyaun Rd, Xili, Nanshan District, Shenzhen City 518055, Guangdong Province, China. ${ }^{5}$ Faculty of Science and Engineering, Curtin University of Technology, Perth, Western Australia, Australia. ${ }^{6}$ Independent Consultant, Salt Lake City, USA.

\section{Received: 23 October 2018 Accepted: 27 December 2018}

\section{Published online: 14 January 2019}

\section{References}

1. Thorpe CT, Screen HRC. Tendon structure and composition. In: Metabolic influences on risk for tendon disorders. 1 edn. Edited by Ackermann PW, Hart DA. Cham: Springer International Publishing; 2016. p. 3-10.

2. O'Brien M. Anatomy of tendons. In: Maffulli N, Renström P, Leadbetter WB editors. Tendon injuries: basic science and clinical medicine. London: Springer London; 2005. p. 3-13.

3. Kastelic J, Galeski A, Baer E. The multicomposite structure of tendon. Connect Tissue Res. 1978;6(1):11-23.

4. Woo SLY, Debski RE, Zeminski J, Abramowitch SD, Chan Saw SS, Fenwick JA. Injury and repair of ligaments and tendons. Annu Rev Biomed Eng. 2000; 2(1):83-118

5. Kalson NS, Holmes DF, Kapacee Z, Otermin I, Lu Y, Ennos RA, Canty-Laird EG, Kadler KE. An experimental model for studying the biomechanics of embryonic tendon: evidence that the development of mechanical properties depends on the actinomyosin machinery. Matrix Biol. 2010; 29(8):678-89.

6. Arnoczky SP, Tian T, Lavagnino M, Gardner K. Ex vivo static tensile loading inhibits MMP-1 expression in rat tail tendon cells through a cytoskeletally based mechanotransduction mechanism. J Orthop Res. 2004;22(2):328-33.

7. Abrahams M. Mechanical behaviour of tendon in vitro. A preliminary report. Med Biol Eng Comp. 1967;5(5):433-43.

8. Couppe C, Hansen P, Kongsgaard M, Kovanen V, Suetta C, Aagaard P, Kjaer M, Magnusson SP. Mechanical properties and collagen cross-linking of the patellar tendon in old and young men. J Appl Physiol. 2009;107(3):880-6.

9. Woo SL-Y, Almarza AJ, Liang R, Fisher MB. Functional tissue engineering of ligament and tendon injuries. In: Translational approaches in tissue engineering and regenerative medicine. Mao JJ, Mikos A, Vunjak-Novakovic G. Boston: Artech House Publishers; 2007. p. 163-179.

10. Calve S, Dennis RG, Kosnik PE, Baar K, Grosh K, Arruda EM. Engineering of functional tendon. Tissue Eng. 2004;10(5-6):755-61.

11. Lavagnino M, Arnoczky SP, Frank K, Tian T. Collagen fibril diameter distribution does not reflect changes in the mechanical properties of in vitro stress-deprived tendons. J Biomech. 2005;38(1):69-75.
12. Rigozzi S, Müller R, Snedeker JG. Local strain measurement reveals a varied regional dependence of tensile tendon mechanics on glycosaminoglycan content. J Biomech. 2009;42(10):1547-52.

13. Goh JC-H, Ouyang H-W, Teoh S-H, Chan CKC, Lee E-H. Tissue-engineering approach to the repair and regeneration of tendons and ligaments. Tissue Eng. 2003;9(supplement 1):31-44.

14. Woo SLY, Almarza AJ, Karaoglu S, Liang R, Fisher MB. Functional tissue engineering of ligament and tendon injuries. In: Principles of regenerative medicine. 2nd ed. San Diego: Academic Press; 2011. p. 997-1021.

15. Paavola $M$, Kannus $P$, Järvinen $T A H$, Khan $K$, Józsa $L$, Järvinen M. Achilles tendinopathy. J Bone Joint Surg. 2002;84-A(11):2062-76.

16. Wang JHC. Mechanobiology of tendon. J Biomech. 2006;39(9):1563-82.

17. James R, Kesturu G, Balian G, Chhabra AB. Tendon: biology, biomechanics, repair, growth factors, and evolving treatment options. J Hand Surg-Am Vol. 2008:33A(1):102-12.

18. Sharma PP, Maffulli NN. Tendon injury and tendinopathy: healing and repair J Bone Joint Surg Am. 2005;87(1):187-202.

19. Thorpe CT, Birch HL, Clegg PD, Screen HRC. The role of the non-collagenous matrix in tendon function. Int J Exp Pathol. 2013;94(4):248-59.

20. Elliott DM, Robinson PS, Gimbel JA, Sarver JJ, Abboud JA, lozzo RV, Soslowsky $\sqcup$. Effect of altered matrix proteins on quasilinear viscoelastic properties in transgenic mouse tail tendons. Ann Biomed Eng. 2003;31(5):599-605.

21. LaCroix AS, Duenwald-kuehl SE, Brickson S, Akins TL, Diffee G, Aiken J, Vanderby R Jr, Lakes RS. Effect of age and exercise on the viscoelastic properties of rat tail tendon. Ann Biomed Eng. 2013;41(6):1120-8.

22. Doral MN, Alam M, Bozkurt M, Turhan E, Atay OA, Dönmez G, Maffulli N Functional anatomy of the Achilles tendon. Knee Surg Sports Traumatol Arthrosc. 2010;18(5):638-43.

23. Butler DL, Grood ES, Noyes FR, Zernicke RF, Brackett K. Effects of structure and strain measurement technique on the material properties of young human tendons and fascia. J Biomech. 1984;17(8):579-96.

24. Abramowitch SD, Zhang X, Curran M, Kilger R. A comparison of the quasistatic mechanical and non-linear viscoelastic properties of the human semitendinosus and gracilis tendons. Clin Biomech. 2010;25(4):325-31.

25. Blanton PL, Biggs NL. Ultimate tensile strength of fetal and adult human tendons. J Biomech. 1970;3(2):181-9.

26. Benedict JV, Walker LB, Harris EH. Stress-strain characteristics and tensile strength of unembalmed human tendon. J Biomech. 1968;1(1):53-63.

27. Cronkite AE. The tensile strength of human tendons. Anat Rec. 1936; 64(2):173-86.

28. Arampatzis A, Stafilidis S, DeMonte G, Karamanidis K, Morey-Klapsing G, Brüggemann GP. Strain and elongation of the human gastrocnemius tendon and aponeurosis during maximal plantarflexion effort. J Biomech. 2005;38(4):833-41.

29. Bogaerts S, Desmet H, Slagmolen P, Peers K. Strain mapping in the Achilles tendon - a systematic review. J Biomech. 2016;49(9):1411-9.

30. Peek AC, Malagelada F, Clark CIM. The Achilles tendon. Orthop Trauma. 2016;30(1):1-7.

31. Freedman BR, Gordon JA, Soslowsky LJ. The Achilles tendon: fundamental properties and mechanisms governing healing. Muscles, Ligaments Tendons J. 2014:4(2):245-55.

32. Kongsgaard M, Aagaard P, Kjaer M, Magnusson SP. Structural Achilles tendon properties in athletes subjected to different exercise modes and in Achilles tendon rupture patients. J Appl Physiol. 2005;99(5):1965-71.

33. Hashemi J, Chandrashekar N, Slauterbeck J. The mechanical properties of the human patellar tendon are correlated to its mass density and are independent of sex. Clin Biomech. 2005;20(6):645-52.

34. Maganaris CN, Narici MV. Mechanical properties of tendons. In: Maffulli N, Renström P, Leadbetter WB, editors. Tendon injuries: basic science and clinical medicine. London: Springer London; 2005. p. 14-21.

35. Butler DL, Grood ES, Noyes FR, Zernicke RF. Biomechanics of tendons and ligaments. Exerc Sport Sci Rev. 1978;6:125-82.

36. Shadwick RE. Elastic energy storage in tendons: mechanical differences related to function and age. J Appl Physiol. 1990;68(3):1033-40.

37. Stenroth L, Cronin NJ, Peltonen J, Korhonen MT, Sipilä S, Finni T. Triceps surae muscle-tendon properties in older endurance- and sprint-trained athletes. J Appl Physiol. 2016;120(1):63-9.

38. Geremia JM, Bobbert MF, Casa Nova M, Ott RD, Lemos Fde A, Lupion Rde O, Frasson VB, Vaz MA. The structural and mechanical properties of the Achilles tendon 2 years after surgical repair. Clin Biomech. 2015; 30(5):485-92. 
39. Hansen P, Bojsen-Moller J, Aagaard P, Kjaer M, Magnusson SP. Mechanical properties of the human patellar tendon, in vivo. Clin Biomech. 2006; 21(1):54-8.

40. Komi PV. Relevance of in vivo force measurements to human biomechanics. J Biomech. 1990;23:23-34.

41. Walden G, Liao X, Donell S, Raxworthy MJ, Riley GP, Saeed A. A clinical, biological, and biomaterials perspective into tendon injuries and regeneration. Tissue Eng B Rev. 2016;23(1):44-58.

42. Flood L, Harrison JE. Epidemiology of basketball and netball injuries that resulted in hospital admission in Australia, 2000-2004. Med J Aust. 2009; 190(2):87.

43. Tallon C, Maffulli N, Ewen SWB. Ruptured Achilles tendons are significantly more degenerated than tendinopathic tendons. Med Sci Sports Exerc. 2001 33(12):1983-90.

44. Kannus P, Józsa L. Histopathological changes preceding spontaneous rupture of a tendon. A controlled study of 891 patients. J Bone Joint Surg. 1991;73(10):1507-25.

45. Helland C, Bojsen-Møller J, Raastad T, Seynnes OR, Moltubakk MM, Jakobsen $V$, Visnes H, Bahr R. Mechanical properties of the patellar tendon in elite volleyball players with and without patellar tendinopathy. Br J Sports Med. 2013;47(13):862-8.

46. Hansen P, Kovanen V, Hölmich P, Krogsgaard M, Hansson P, Dahl M, Hald M, Aagaard P, Kjaer M, Magnusson SP. Micromechanical properties and collagen composition of ruptured human Achilles tendon. Am J Sports Med. 2013:41(2):437-43.

47. Arya S, Kulig K. Tendinopathy alters mechanical and material properties of the Achilles tendon. J Appl Physiol. 2010;108(3):670-5.

48. Almekinders LC, Weinhold PS, Maffulli N. Compression etiology in tendinopathy. Clin Sports Med. 2003;22(4):703-10.

49. Maffulli N. Overuse tendon conditions: time to change a confusing terminology. Arthroscopy. 1998;14(8):840-3.

50. Albers IS, Zwerver J, Diercks RL, Dekker JH, Van den Akker-Scheek I. Incidence and prevalence of lower extremity tendinopathy in a Dutch general practice population: a cross sectional study. BMC Musculoskelet Disord. 2016;17:16

51. de Jonge $S$, van den Berg $C$, de Vos RJ, van der Heide HJ, Weir A Verhaar JA, Bierma-Zeinstra SM, Tol JL. Incidence of midportion Achilles tendinopathy in the general population. Br J Sports Med. 2011;45(13):1026-8

52. Yasui $Y$, Tonogai I, Rosenbaum AJ, Shimozono Y, Kawano H, Kennedy JG. The risk of Achilles tendon rupture in the patients with Achilles tendinopathy: healthcare database analysis in the United States. Biomed Res Int. 2017; 2017:7021862.

53. Rodenberg RE, Bowman E, Ravindran R. Overuse injuries. Prim Care. 2013; 40(2):453-73.

54. Arnoczky SP, Lavagnino M, Egerbacher M. The mechanobiological aetiopathogenesis of tendinopathy: is it the over-stimulation or the understimulation of tendon cells? Int J Exp Pathol. 2007:88(4):217-26.

55. Rees JD, Maffulli N, Cook J. Management of tendinopathy. Am J Sports Med. 2009;37(9):1855-67.

56. Almekinders LC. Etiology, diagnosis, and treatment of tendonitis: an analysis of the literature. Med Sci Sports Exerc. 1998;30(8):1183-90.

57. Maffulli N, Via AG, Oliva F. Chronic Achilles tendon disorders: tendinopathy and chronic rupture. Clin Sports Med. 2015;34(4):607-24.

58. Seitz AM, Wolfram U, Wiedenmann C, Ignatius A, Dürselen L. Impact of measurement errors on the determination of the linear modulus of human meniscal attachments. J Mech Behav Biomed Mater. 2012;10(1):120-7.

59. Pokhai GG, Oliver ML, Gordon KD. A new laser reflectance system capable of measuring changing cross-sectional area of soft tissues during tensile testing. J Biomech Eng. 2009;131(9):094504.

60. Langelier E, Dupuis D, Guillot M, Goulet F, Rancourt D. Cross-sectional profiles and volume reconstructions of soft tissues using laser beam measurement. J Biomech Eng. 2004;126(6):796-802.

61. Grawe BM, Williams PN, Burge A, Voigt M, Altchek DW, Hannafin JA, Allen AA. Anterior cruciate ligament reconstruction with autologous hamstring: can preoperative magnetic resonance imaging accurately predict graft diameter? Orthop J Sports Med. 2016;4(5):2325967116646360

62. Leiter J, Elkurbo M, McRae S, Chiu J, Froese W, MacDonald P. Using preoperative MRI to predict intraoperative hamstring graft size for anterior cruciate ligament reconstruction. Knee Surg Sports Traumatol Arthrosc. 2017;25(1):229-35
63. Yasumoto M, Deie M, Sunagawa T, Adachi N, Kobayashi K, Ochi M. Predictive value of preoperative 3-dimensional computer tomography measurement of semitendinosus tendon harvested for anterior cruciate ligament reconstruction. Arthroscopy. 2006;22(3):259-64.

64. Vergari C, Pourcelot P, Holden L, Ravary-Plumioën B, Laugier P, Mitton D, Crevier-Denoix N. A linear laser scanner to measure cross-sectional shape and area of biological specimens during mechanical testing. J Biomech Eng. 2010;132(10):105001.

65. Pierre-Jerome C, Moncayo V, Terk MR. MRI of the Achilles tendon: a comprehensive review of the anatomy, biomechanics, and imaging of overuse tendinopathies. Acta Radiol. 2010;51(4):438-54.

66. Rasmussen OS. Sonography of tendons. Scand J Med Sci Sports. 2000; 10(6):360-4.

67. Schepull T, Kvist J, Norrman H, Trinks M, Berlin G, Aspenberg P. Autologous platelets have no effect on the healing of human achilles tendon ruptures: a randomized single-blind study. Am J Sports Med. 2011;39(1):38-47.

68. Balint R, Lowe T, Shearer T. Optimal contrast agent staining of ligaments and tendons for X-ray computed tomography. PLoS One. 2016;11(4):e0153552.

69. Faraj KA, Cuijpers VMJI, Wismans RG, Walboomers XF, Jansen JA, van Kuppevelt TH, Daamen WF. Micro-computed tomographical imaging of soft biological materials using contrast techniques. Tissue Eng Part C: Methods. 2009;15(3):493-9.

70. Arampatzis A, Peper A, Bierbaum S, Albracht K. Plasticity of human Achilles tendon mechanical and morphological properties in response to cyclic strain. J Biomech. 2010;43(16):3073-9.

71. Hansen P, Aagaard P, Kjaer M, Larsson B, Magnusson SP. Effect of habitual running on human Achilles tendon load-deformation properties and crosssectional area. J Appl Physiol (1985). 2003;95(6):2375-80.

72. Stecco C, Cappellari A, Macchi V, Porzionato A, Morra A, Berizzi A, De Caro R. The paratendineous tissues: an anatomical study of their role in the pathogenesis of tendinopathy. Surg Radiol Anat. 2014;36(6): 561-72.

73. Ekizos A, Papatzika F, Charcharis G, Bohm S, Mersmann F, Arampatzis A. Ultrasound does not provide reliable results for the measurement of the patellar tendon cross sectional area. J Electromyogr Kinesiol. 2013;23(6): 1278-82.

74. Yoo JH, Yi SR, Kim JH. The geometry of patella and patellar tendon measured on knee MRI. Surg Radiol Anat. 2007;29(8):623-8.

75. Goldstein JL, Verma N, McNickle AG, Zelazny A, Ghodadra N, Bach BR Jr. Avoiding mismatch in allograft anterior cruciate ligament reconstruction: correlation between patient height and patellar tendon length. Arthroscopy. 2010;26(5):643-50.

76. Chang CB, Seong SC, Kim TK. Preoperative magnetic resonance assessment of patellar tendon dimensions for graft selection in anterior cruciate ligament reconstruction. Am J Sports Med. 2009;37(2):376-82.

77. Bickel BA, Fowler TT, Mowbray JG, Adler B, Klingele K, Phillips G. Preoperative magnetic resonance imaging cross-sectional area for the measurement of hamstring autograft diameter for reconstruction of the adolescent anterior cruciate ligament. Arthroscopy. 2008:24(12):1336-41.

78. Erquicia Jl, Gelber PE, Doreste JL, Pelfort X, Abat F, Monllau JC. How to improve the prediction of quadrupled semitendinosus and gracilis autograft sizes with magnetic resonance imaging and ultrasonography. Am J Sports Med. 2013:41(8):1857-63.

79. Galanis N, Savvidis M, Tsifountoudis I, Gkouvas G, Alafropatis I, Kirkos J, Kellis E. Correlation between semitendinosus and gracilis tendon crosssectional area determined using ultrasound, magnetic resonance imaging and intraoperative tendon measurements. J Electromyogr Kinesiol. 2016:26:44-51.

80. Beyzadeoglu T, Akgun U, Tasdelen N, Karahan M. Prediction of semitendinosus and gracilis autograft sizes for ACL reconstruction. Knee Surg Sports Traumatol Arthrosc. 2012;20(7):1293-7.

81. Wernecke G, Harris IA, Houang MT, Seeto BG, Chen DB, MacDessi SJ. Using magnetic resonance imaging to predict adequate graft diameters for autologous hamstring double-bundle anterior cruciate ligament reconstruction. Arthroscopy. 2011;27(8):1055-9.

82. Ilahi OA, Staewen RS, Stautberg EF 3rd, Qadeer AA. Estimating lengths of semitendinosus and gracilis tendons by magnetic resonance imaging. Arthroscopy. 2018;34(8):2457-62.

83. Hamada M, Shino K, Mitsuoka T, Abe N, Horibe S. Cross-sectional area measurement of the semitendinosus tendon for anterior cruciate ligament reconstruction. Arthroscopy. 1998;14(7):696-701. 
84. Couppe C, Svensson RB, Sodring-Elbrond V, Hansen P, Kjaer M, Magnusson SP. Accuracy of MRI technique in measuring tendon cross-sectional area. Clin Physiol Funct Imaging. 2014;34(3):237-41.

85. Patel NN, Labib SA. The Achilles tendon in healthy subjects: an anthropometric and ultrasound mapping study. J Foot Ankle Surg. 2018; 57(2):285-8

86. Skou ST, Aalkjaer JM. Ultrasonographic measurement of patellar tendon thickness--a study of intra- and interobserver reliability. Clin Imaging. 2013; 37(5):934-7.

87. Reeves ND, Maganaris CN, Maffulli N, Rittweger J. Human patellar tendon stiffness is restored following graft harvest for anterior cruciate ligament surgery. J Biomech. 2009;42(7):797-803.

88. Reeves ND, Maganaris CN, Narici MV. Effect of strength training on human patella tendon mechanical properties of older individuals. J Physiol. 2003; 548(3):971-81.

89. O'Brien TD, Reeves ND, Baltzopoulos V, Jones DA, Maganaris CN. Mechanical properties of the patellar tendon in adults and children. J Biomech. 2010; 43(6):1190-5.

90. Jacobson JA. Musculoskeletal ultrasound: focused impact on MRI. AJR Am J Roentgenol. 2009;193(3):619-27.

91. Dudley-Javoroski S, McMullen T, Borgwardt MR, Peranich LM, Shields RK. Reliability and responsiveness of musculoskeletal ultrasound in subjects with and without spinal cord injury. Ultrasound Med Biol. 2010;36(10):1594-607.

92. Foure A, Nordez A, McNair P, Cornu C. Effects of plyometric training on both active and passive parts of the plantarflexors series elastic component stiffness of muscle-tendon complex. Eur J Appl Physiol. 2011;111(3):539-48.

93. Intziegianni K, Cassel M, König N, Müller S, Fröhlich K, Mayer F. Ultrasonography for the assessment of the structural properties of the Achilles tendon in asymptomatic individuals: an intra-rater reproducibility study. Isokinet Exerc Sci. 2015;23(4):263-70.

94. Kubo K, Teshima T, Hirose N, Tsunoda N. A cross-sectional study of the plantar flexor muscle and tendon during growth. Int J Sports Med. 2014; 35(10):828-34

95. Milgrom Y, Milgrom C, Altaras T, Globus O, Zeltzer E, Finestone AS. Achilles tendons hypertrophy in response to high loading training. Foot Ankle Int. 2014;35(12):1303-8.

96. Ying M, Yeung E, Li B, Li W, Lui M, Tsoi C-W. Sonographic evaluation of the size of achilles tendon: the effect of exercise and dominance of the ankle. Ultrasound Med Biol. 2003;29(5):637-42.

97. Waugh CM, Blazevich AJ, Fath F, Korff T. Age-related changes in mechanical properties of the Achilles tendon. J Anat. 2012;220(2):144-55.

98. Oliveira LF, Peixinho CC, Silva GA, Menegaldo LL. In vivo passive mechanica properties estimation of Achilles tendon using ultrasound. J Biomech. 2016; 49(4):507-13.

99. Baki AE, Yildizgoren MT, Kara M, Ekiz T, Tutkun E, Ozcakar L. Ultrasonographic measurement of the Achilles and supraspinatus tendon thicknesses in patients with chronic lead exposure. West Indian Med J. 2015; 64(4):384-7.

100. Emerson C, Morrissey D, Perry M, Jalan R. Ultrasonographically detected changes in Achilles tendons and self reported symptoms in elite gymnasts compared with controls--an observational study. Man Ther 2010;15(1):37-42.

101. Foure A, Nordez A, Cornu C. Plyometric training effects on Achilles tendon stiffness and dissipative properties. J Appl Physiol (1985). 2010;109(3):849-54.

102. Intziegianni K, Cassel M, Fröhlich K, Engel T, Mayer F. Measuring Achilles tendon length: a simple and reliable method. Sports Orthop Traumatol Sport-Orthopädie - Sport-Traumatologie. 2015;31(4):260-6.

103. Intziegianni K, Cassel M, Hain G, Mayer F. Gender differences of Achilles tendon cross-sectional area during loading. Sports Med Int Open. 2017; 1(04):E135-40.

104. Magnusson SP, Aagaard P, Rosager S, Dyhre-Poulsen P, Kjaer M. Loaddisplacement properties of the human triceps surae aponeurosis in vivo. J Physiol. 2001:531(Pt 1):277-88.

105. Toprak U, Ustuner E, Uyanik S, Aktas G, Kinikli Gl, Baltaci G, Karademir MA. Comparison of ultrasonographic patellar tendon evaluation methods in elite junior female volleyball players: thickness versus cross-sectional area. Diagn Interv Radiol. 2012;18(2):200-7.

106. Wiley JP, Bray RC, Wiseman DA, Elliott PD, Ladly KO, Vale LA. Serial ultrasonographic imaging evaluation of the patellar tendon after harvesting its central one third for anterior cruciate ligament reconstruction. J Ultrasound Med. 1997;16(4):251-5.
107. Gellhorn AC, Carlson MJ. Inter-rater, intra-rater, and inter-machine reliability of quantitative ultrasound measurements of the patellar tendon. Ultrasound Med Biol. 2013;39(5):791-6.

108. McAuliffe S, McCreesh K, Purtill H, O'Sullivan K. A systematic review of the reliability of diagnostic ultrasound imaging in measuring tendon size: is the error clinically acceptable? Phys Ther Sport. 2017;26:52-63.

109. Astur DDC, Novaretti JV, Liggieri AC, Janovsky C, Nicolini AP, Cohen M. Ultrasonography for evaluation of hamstring tendon diameter: is it possible to predict the size of the graft? Rev Bras Ortop. 2018;53(4):404-9.

110. Kruse A, Stafilidis S, Tilp M. Ultrasound and magnetic resonance imaging are not interchangeable to assess the Achilles tendon cross-sectional-area. Eur J Appl Physiol. 2017;117(1):73-82.

111. Barfod KW, Riecke AF, Boesen A, Hansen P, Maier JF, Dossing S, Troelsen A. Validation of a novel ultrasound measurement of achilles tendon length. Knee Surg Sports Traumatol Arthrosc. 2015;23(11):3398-406.

112. Bohm S, Mersmann F, Schroll A, Makitalo N, Arampatzis A. Insufficient accuracy of the ultrasound-based determination of Achilles tendon crosssectional area. J Biomech. 2016;49(13):2932-7.

113. Brushoj C, Henriksen BM, Albrecht-Beste E, Holmich P, Larsen K, Bachmann Nielsen M. Reproducibility of ultrasound and magnetic resonance imaging measurements of tendon size. Acta Radiol. 2006;47(9):954-9.

114. Noguchi M, Kitaura T, Ikoma K, Kusaka Y. A method of in-vitro measurement of the cross-sectional area of soft tissues, using ultrasonography. J Orthop Sci. 2002;7(2):247-51.

115. Du Y-C, Chen Y-F, Li C-M, Lin C-H, Yang C-E, Wu J-X, Chen T. Quantitative ultrasound method for assessing stress-strain properties and the crosssectional area of Achilles tendon. Meas Sci Technol. 2013;24(12):125702.

116. Obst SJ, Renault J-B, Newsham-West R, Barrett RS. Three-dimensional deformation and transverse rotation of the human free Achilles tendon in vivo during isometric plantarflexion contraction. J Appl Physiol. 2014;116(4): 376-84.

117. Obst SJ, Newsham-West R, Barrett RS. In vivo measurement of human Achilles tendon morphology using freehand 3-D ultrasound. Ultrasound Med Biol. 2014;40(1):62-70.

118. Nuri L, Obst SJ, Newsham-West R, Barrett RS. The tendinopathic Achilles tendon does not remain iso-volumetric upon repeated loading: insights from 3D ultrasound. J Exp Biol. 2017;220(Pt 17):3053-61.

119. Nuri L, Obst SJ, Newsham-West R, Barrett RS. Regional three-dimensional deformation of human Achilles tendon during conditioning. Scand J Med Sci Sports. 2017;27(11):1263-72.

120. Nuri L, Obst SJ, Newsham-West R, Barrett RS. Recovery of human Achilles tendon three-dimensional deformation following conditioning. J Sci Med Sport. 2018;21(5):473-8.

121. Obst SJ, Newsham-West R, Barrett RS. Changes in Achilles tendon mechanical properties following eccentric heel drop exercise are specific to the free tendon. Scand J Med Sci Sports. 2016;26(4):421-31.

122. Fan G. 3D anatomical investigation of Achilles tendon using a freehand ultrasound imaging system. In: Bioinformatics and biomedical engineering (iCBBE), 2010 4th international conference on: 18-20 June 2010. Chengdu: IEEE; 2010. p. 1-3.

123. Kartus J, Rostgard-Christensen L, Movin T, Lindahl S, Ejerhed L, Karlsson J. Evaluation of harvested and normal patellar tendons: a reliability analyses of magnetic resonance imaging and ultrasonography. Knee Surg Sports Traumatol Arthrosc. 2000;8(5):275-80.

124. Chatzistergos PE, Tsitsilonis SI, Mitousoudis AS, Perrea DN, Zoubos AB, Kourkoulis SK. The fracture stress of rat Achilles tendons. Scand J Lab Anim Sci. 2010;37(3):149-56.

125. Iriuchishima T, Yorifuji H, Aizawa S, Tajika Y, Murakami T, Fu FH. Evaluation of $\mathrm{ACL}$ mid-substance cross-sectional area for reconstructed autograft selection. Knee Surg Sports Traumatol Arthrosc. 2014;22(1): 207-13.

126. Ellis DG. Cross-sectional area measurements for tendon specimens: a comparison of several methods. J Biomech. 1969;2(2):175-86.

127. Allard P, Thiry PS, Bourgault A, Drouin G. Pressure dependence of 'the area micrometer' method in evaluation of cruciate ligament cross-section. J Biomed Eng. 1979;1(4):265-7.

128. Butler DL, Kay MD, Stouffer DC. Comparison of material properties in fascicle-bone units from human patellar tendon and knee ligaments. J Biomech. 1986;19(6):425-32.

129. Race A, Amis AA. Cross-sectional area measurement of soft tissue. A new casting method. J Biomech. 1996;29(9):1207-12. 
130. Goodship AE, Birch HL. Cross sectional area measurement of tendon and ligament in vitro: a simple, rapid, non-destructive technique. J Biomech. 2005;38(3):605-8.

131. Schmidt KH, Ledoux WR. Quantifying ligament cross-sectional area via molding and casting. J Biomech Eng. 2010;132(9):091012.

132. Lee TQ, Woo SL-Y. A new method for determining cross-sectional shape and area of soft tissues. J Biomech Eng. 1988;110(2):110-4.

133. Smutz WP, Drexler M, Berglund LJ, Growney E, An KN. Accuracy of a video strain measurement system. J Biomech. 1996;29(6):813-7.

134. Moon DK, Abramowitch SD, Woo SL-Y. The development and validation of a charge-coupled device laser reflectance system to measure the complex cross-sectional shape and area of soft tissues. J Biomech. 2006;39(16):3071-5.

135. Januário AL, Barriviera M, Duarte WR. Soft tissue cone-beam computed tomography: a novel method for the measurement of gingival tissue and the dimensions of the dentogingival unit. J Esthet Restor Dent. 2008;20(6): 366-73.

136. Durrington PN, Adams JE, Beastall MD. The assessment of achilles tendon size in primary hypercholesterolaemia by computed tomography. Atherosclerosis. 1982;45(3):345-58.

137. Kainberger F, Mittermaier F, Seidl G, Parth E, Weinstabl R. Imaging of tendons - adaptation, degeneration, rupture. Eur J Radiol. 1997;25(3):209-22.

138. Doherty GP, Koike Y, Uhthoff HK, Lecompte M, Trudel G. Comparative anatomy of rabbit and human Achilles tendons with magnetic resonance and ultrasound imaging. Comp Med. 2006;56(1):68-74.

139. Liu MJJ, Chou SM, Goh KL, Tan SH. Cross-sectional area measurement of soft tissues in vitro: a non-contact laser scan method. J Mech Med Biol. 2008;8(3):353-61.

140. Salisbury STS, Buckley CP, Zavatsky AB. Image-based non-contact method to measure cross-sectional areas and shapes of tendons and ligaments. Meas Sci Technol. 2008;19(4):045705+045709.

141. Woo SL-Y, Danto MI, Ohland KJ, Lee TQ, Newton PO. The use of a laser micrometer system to determine the cross-sectional shape and area of ligaments: a comparative study with two existing methods. J Biomech Eng. 1990;112(4):426-31.

142. Heuer F, Wolfram U, Schmidt H, Wilke H-J. A method to obtain surface strains of soft tissues using a laser scanning device. J Biomech. 2008; 41(11):2402-10.

143. Hashemi J, Chandrashekar N, Cowden C, Slauterbeck J. An alternative method of anthropometry of anterior cruciate ligament through 3-D digital image reconstruction. J Biomech. 2005;38(3):551-5.

144. Nebel J-C. Soft tissue modelling from 3D scanned Data. In: Deformable Avatars: IFIP TC5/WG510 DEFORM'2000 Workshop November 29-30, 2000 Geneva, Switzerland and AVATARS'2000 Workshop November 30-December 1, 2000 Lausanne, Switzerland. edn. Edited by Magnenat-Thalmann N, ThalmannD. Boston, MA: Springer US; 2001. p. 85-97.

145. Ahn H-W, Chang Y-J, Kim K-A, Joo S-H, Park Y-G, Park K-H. Measurement of three-dimensional perioral soft tissue changes in dentoalveolar protrusion patients after orthodontic treatment using a structured light scanner. Angle Orthod. 2014;84(5):795-802.

146. Hayes A, Easton K, Devanaboyina PT, Wu J-P, Kirk TB, Lloyd D. Structured white light scanning of rabbit Achilles tendon. J Biomech. 2016;49(15):3753-8.

147. Spera D, Genovese K, Voloshin A. Application of stereo-digital image correlation to full-field 3-D deformation measurement of intervertebral disc. Strain. 2011:47:e572-87.

148. Pyne JD, Genovese K, Casaletto L, Vande Geest JP. Sequential-digital image correlation for mapping human posterior sclera and optic nerve head deformation. J Biomech Eng. 2014;136(2):021002-021002.

149. Lionello G, Sirieix C, Baleani M. An effective procedure to create a speckle pattern on biological soft tissue for digital image correlation measurements. J Mech Behav Biomed Mater. 2014;39(0):1-8.

150. Genovese K, Lee YU, Lee AY, Humphrey JD. An improved panoramic digital image correlation method for vascular strain analysis and material characterization. J Mech Behav Biomed Mater. 2013;27(0):132-42.

151. Genovese K, Lee YU, Humphrey JD. Novel optical system for in vitro quantification of full surface strain fields in small arteries: II. Correction for refraction and illustrative results. Comp Methods Biomech Biomed Engin. 2011;14(3):227-37.

152. Tung S-H, Shih M-H, Kuo J-C. Application of digital image correlation for anisotropic plastic deformation during tension testing. Opt Lasers Eng. 2010; 48(5):636-41.
153. Gao Z, Desai JP. Estimating zero-strain states of very soft tissue under gravity loading using digital image correlation. Med Image Anal. 2010; 14(2):126-37.

154. Chen J, Xia G, Zhou K, Xia G, Qin Y. Two-step digital image correlation for micro-region measurement. Opt Lasers Eng. 2005;43(8):836-46.

155. Evans SL, Holt CA, Ozturk H, Saidi K, Shrive NG. Measuring soft tissue properties using digital image correlation and finite element modelling. In: Gdoutos EE, editor. Experimental analysis of nano and engineering materials and structures. Netherlands: Springer; 2007. p. 313-4.

\section{Ready to submit your research? Choose BMC and benefit from:}

- fast, convenient online submission

- thorough peer review by experienced researchers in your field

- rapid publication on acceptance

- support for research data, including large and complex data types

- gold Open Access which fosters wider collaboration and increased citations

- maximum visibility for your research: over $100 \mathrm{M}$ website views per year

At $\mathrm{BMC}$, research is always in progress.

Learn more biomedcentral.com/submissions 